\title{
Framing the Globalization-Migration Debate: Continuing Impact of U.S. Economic Crises on Indian H1-B Immigrant Professionals in America
}

\author{
Ishani Mukherjee, Ph.D. \\ University of Illinois at Chicago, Chicago, IL, USA
}

\begin{abstract}
The politics of migration though not novel has been given a renewed meaning by the processes of globalization and transnationalism, especially by way of providing heightened economic opportunities to foreign professionals in developed host countries. However, the aftermath of recent economic recession in North America has created a continued climate of professional uncertainty for several employment-based immigrant professionals, including Asian-Indian immigrants who possess specialized skills and are currently working in the U.S. on employment-based visas such as the H1-B visa category. In the context of the debate between economic self-interest and localized state-interest, it is imperative to examine the frames of political and socio-cultural discourse surrounding the debate, especially to enquire, 'who the agents framing the processes of globalization, migration and localization are,' and 'which rhetorical frame/s are most salient in terms of creating a consensus between economic stability and continued migration?' Using the Asian-Indian immigration-uncertainty model as a case study for the fiscal and international labor-relation fallout of the U.S. economic meltdown, this essay will critically review consequences of attitudes toward U.S. immigration policies within the last decade, and their economic, cultural, and political effects on the substantially large, professional Indian diaspora.
\end{abstract}

Keywords: Framing, Globalization, Immigration, Indian H1-B Professionals, U.S. Economic Crises

\section{Introduction}

Attributing strict immigration policies of high-income nations as a major obstacle to globalization, Martin Wolf argues, "these controls on migration create the world's biggest economic distortion - the discrepancy in rewards to labor" [1]. Wolf's statement seems an apparent contradiction in terms. Yet, his "obvious answer: free migration" [1], or at least the exercise of more lenient immigration policies and controls, can be seen as a way out of the professional uncertainty that recent immigrants in the United States of America are facing as a result of the $21^{\text {st }}$ century global economic downturn? In particular, how does it affect the professional and skilled Asian-Indian transnational minority who, as an active part of the globalized free-trade market are also facing the brunt of the continuing U.S. economic crises? In response to the above questions, the larger goal of this critical review is to theoretically evaluate and potentially address some of the economic, political and cultural frames dominating the incessant migration-globalization debate within the last decade, particularly bearing in mind the case study of recently migrated Asian-Indian high-skilled professionals in the United States of America.

The politics of migration though not novel has been given a renewed meaning by the process of globalization, especially by way of providing economic opportunities and heightened legal stability to foreign professionals in developed host countries. Indian immigrants who possess specialized knowhow and are currently working in the U.S. on employment-based visas such as the H1-B visa category, serve as the ideal case study for scholars interested in theorizing this global-transnational problematic in action. For most Indian transnationals', the eventual assurance of U.S. permanent residency or citizenship acts as extra impetus to strengthen the host economy by reducing the additional operational costs of conducting business overseas and by applying the special skill set that they have imported from their home country. The supporters of globalization and immigration see advantages in greater integration of immigrants in the recipient country, in terms of economic, cultural, political and social diversification. However, the upholders of localization fear that as a result of the backlash of liberal economic globalization, the strength of the culture and political system of the host country will be compromised by immigrants who are drawn to migrate solely for economic reasons, without any need to successfully assimilate into the host society. Whether the argument for porous borders accelerates or decelerates the process of globalization is also in part determined by current flows, both back and forth, of Indian immigrants to the U.S. and homeward. This argument becomes particularly salient postrecession, given the fact that several South Asians have in recent times returned to their home countries to 
escape economic backlash, post-depression fiscal stagnancy and the associated legal insecurity that comes with it.

In the context of this dichotomy between economic self-interest and localized state-interest, it seems imperative to examine the frames of political and socio-cultural discourse surrounding the debate, especially to enquire, 'who the agents framing the processes of globalization, migration and localization are,' and 'which rhetorical frame/s are most salient in terms of creating a consensus between assured economic stability and continued migration flows?' Using the Asian-Indian immigration-uncertainty model as a case study for the fiscal and international labor-relation fallout of the continuing U.S. economic meltdown, this essay will critically review the consequences of attitudes toward U.S. immigration policies within the last decade, and the resultant economic, cultural, and political effects on the substantially large, professional Indian diaspora.

\section{Case Study - Skilled Indian Immigrants In Post-Recession U.S.}

The immigration debate in the U.S. has long focused on the economic contributions of illegal immigrants, but with rising unemployment exacerbated by the recent recession, legalized skilled immigrants on H-1B employment visas (for foreign nationals) have come under the debate spotlight. The U.S. Immigration and Nationality Act grants the H-1B visa holders the authority to work in a highly skilled, specialized profession that requires theoretical and practical knowhow, supported by a specific course of higher education. Of the approximate 115,000 skilled immigrant workers who come to the U.S. annually, the "Regular" cap on new H$1 \mathrm{~B}$ visas is 65,000 (distributed to the for-profit sector employers through a lottery held by the U.S. Citizenship and Immigration Services), with around 20,000 visas exempted for skilled workers with U.S. masters degrees [2] [3]. This numerical quota excludes H1-B visas set aside for skilled foreign professionals who claim employment in not-for profit sectors such as at U.S. universities, social service organizations, etc. Of course, these non-profit H1-Bs are not 'capped' because of the negligible demand for related jobs compared to those in the for-profit corporate and information technology (IT) sectors, even within this environment of fiscal unpredictability. Pundits in the field of globalization and immigration have identified that even in the climate of current economic instability, the "demand far outpaced supply, and convincing Congress to raise the cap has been a legislative priority for many, particularly high-tech employers" [2].

Until recently, about $25 \%$ of graduates from India's four most prestigious technology institutes, including the Indian Institutes of Technology (IITs), immigrated to the U.S. to enroll in specialized, higher education courses and get employment in the IT sectors. More than $30 \%$ of the ventures and software firms in Silicon Valley were started by Asians, a large number being Indians [4]. In fact, so symbiotic has been the relation between technology graduates of Indian and U.S. universities (in particular IIT/technology students), that funding for IITs by non-resident Indians (NRIs), in return for re-structuring IIT courses on the guidelines of American science and technology universities, led to a lot of controversy among Indian patriots. Growing concerns included the privileged status of NRIs in the U.S., particularly in the eyes of the Indian government, as well as the profitable structural position of many Indians, both in India and within the global economy. Part of the loyalist dissatisfaction also arose from what is popularly known as the myth of return, wherein skilled immigrants who had promised themselves and their Indian compatriots that their stay in the U.S. would only be temporary, failed to keep their promise. This attitude determined many Indian-Americans' transnational orientation, since everyone [including Indian localists, who anticipated the return of sons (and daughters) of the soil] seemed prepared to go back to India the very "next year" [5].

Immigration scholar Johanna Lessinger believes that this outflow of highly trained immigrants, who might have otherwise helped India in the global scuttle for economic growth, symbolizes either a reverse braindrain that weakens India's talent resources, or a positive development that marks India's contribution to a transnational class of high-tech entrepreneurs, by giving, what is still considered a developing country, advantageous access to the global economy [5]. Albeit, this also has a bearing on more scholarly debates about the extent to which the forces of globalization and transnationalism rupture the national identities and traditional state boundaries of the immigrant communities.

In other words, the globalization of this migration has for long been a way for skilled talent to find economic opportunities and vice versa [5]. To the displeasure of many labor-rights organizations and antiglobalization camps, skilled immigrants are often seen as one of the first steps to globalization, the thought generating from the idea that Americans are either not qualified enough or altogether unwilling to do certain jobs. According to the vice president of a multinational corporation KBACE the key to being competitive is to garner global talent by getting "the right person at the right time with the right set of skills," and to that tune, "about one-tenth of its 450 employees hold H-1B visas or (have) received intra-company transfers from operations in India" [2]. Using data from the 2000 census on immigrant impact on U.S. economy, scholars William R. Kerr of the Harvard Business School and William F. Lincoln of the University of Michigan report that about $67 \%$ of growth in the U.S. science and engineering workforce was generated by immigrants [2]. 
On the other end of the spectrum, accusations are that skilled immigrant workers are dislocating U.S. workers within a weakening economy. As an undesired fallout of the Troubled Asset Relief Program (TARP, 2009), U.S. Congress had enforced stringent limits on U.S. firms receiving bailout money from hiring Indians on H-1B visas to fill higher posts, especially if they were laying-off American nationals. Congressman Bernie Sanders, who together with Sen. Grassley had during the time enforced these rules as part of the ARRA (American Recovery Reinvestment Act, 2009), argued that "the very least we can do is to make sure that banks receiving a taxpayer bailout are not allowed to import cheaper labor from overseas while they are throwing American workers out" [2].

As an accrued result of the past five years of economic and political backfiring, there has been a lot of concern among the Indian immigrant population regarding the attitudes of the government toward tightening U.S. immigration policies, especially in the post $9 / 11$ context, which has made the legal status of several H1-Bholding Indians in the host country, questionable at the very least. According to the U.S. Census Bureau's 2008 report, the economic crisis has resulted in a drop of almost $7.3 \%$ in the household income of non-U.S. citizens and skilled immigrant workers. As a post-snowball effect, the U.S. financial crisis has led to a growing deterioration of several South Asian economies, including India, where software corporations and the financial sectors rely heavily on customers in the U.S. [6].

While the upholders of localization point to the glass as being half-full by positing that outsourcing jobs to countries like India will not be affected at all, if not increase further, the opponents of reverseglobalization (such as the American Immigration Lawyers Association), argue that the current government's immigration restriction policies are very likely to deprive the U.S. of some of the best global talent in the form of skilled labor [4]. Additionally, there has been considerable amount of speculation among employment-based immigrant communities about their jobs still being intact by the time Congress decides to implement (if at all) the Comprehensive Immigration Reform programs, which according to some optimists and globalization gurus will be able to counter the economic meltdown by bringing in more skilled immigrant workers [7]. It is true that limits on immigration like free-trade restrictions have a pragmatic impact, as they undermine the economy further. However, there is little possibility for the immigration debate to reach a consensus unless there happens to be at some point a convergence of political interests and economic incentives to the betterment of both the host economy and immigrant communities.

\section{Globalization, Localization and Highly Skilled Transnationals}

Wolf defines globalization (specifically, economic globalization), as a combination of economic activities, through markets. The driving forces are primarily technological and policy changes, marked by the falling costs of transportation and communication, along with greater reliance on market forces [1]. He believes that a global market economy, driven by classical liberal democracy and co-operative global governance is what makes globalization work and nations function more effectively. However, Wolf agrees, "globalization is not rampant. It remains remarkably limited," given the reality that high-income nations levy a brunt of subsidies and protectionist trade barriers on low-income nations and advocate restrictive immigration policies to the detriment of global economic liberalization [1].

Some economic globalization exponents argue that to counter the inadequate political policies that nation-states make in terms of immigration, global cities should actively form a part of the global production process that constitutes the "capability for global control" [8]. According to Saskia Sassen [8] [9], global cities are primarily the hubs of national and international transactions comprising various immigrant groups, most of them being top-level professional immigrant workers. So, if one ascribes to Sassen's view that the global city is a function of a cross-border network of strategic sites [9], it could prove helpful to examine the implications of the current U.S. immigration policies and their economic, cultural and political effects on how immigrants can significantly contribute to global cities' development and accomplishment, particularly in the context of the post-economic crisis phase. That said, the abovementioned is the subject matter of considerable import that cannot be justly addressed within the length of this paper. Thus for the purpose of this essay, the viability of the U.S. as a global economy that supports skilled labor immigration within a neo-liberal market order, purporting a progressive economic, cultural and political policy paradigm, is being questioned. It is also imperative to explicate the individual concepts and constructs that form the crux of this issue.

It has been known for quite some time that the conservative position of the U.S. has been to welcome foreigners in the form of skilled immigrant workers, viewed as a "natural consequence of interdependence" [10]. According to Kunal M. Parker [11], immigration precedes globalization, being an age-old process, but globalization has definitely modified migration as a result of advances in technology and communication wherein immigrants can equally correspond with their home and host countries. Complete assimilation into the recipient community is no longer a necessity, as "several countries encourage immigrants to maintain ties with their home country by creating laws that protect property rights of absent individuals and laws that enable immigrants to be dual citizens" [11]. The proponents of globalization see many benefits in the immigration of 
skilled workers, owing to the fact that they bring with them proficient expertise that helps to reduce transactional costs related to international business practices of developed nations [11]. On the flipside, globalization critics believe that the unchecked immigration of skilled workers leads to divided communities made up of incomplete assimilation patterns [11]. As evident, the issue of immigration runs much deeper than the mere import of labor that enhances the host nation's economy. In fact, it impacts "the social make-up, law and order, and the hollow but widely regarded concept of a "collective identity". And as a result it impacts politics" [12].

The current U.S. restrictions on immigration are similar to the restrictions placed by socialist countries on goods trade, most of them being non-sustainable given the fact that they are enforced, not on grounds of being immoral, but rather, being conscious political decisions based on a pseudo-patriotism, which will only serve to undermine the global economy and the people within it [12]. Wolf agrees that technological and communication advances have pushed the world towards globalization, but he also agrees that distance as a delimiting factor to international market integration is still very much present, especially within the labor market, which will perhaps never be that itinerant given the restrictionist policies of many an advanced governmental infrastructure [1]. It is economically and politically unwise of these countries to erect barriers that prevent them from taking advantage of a global resource-pool of talent and skills [1].

For Martin Wolf, globalization, defined as an integration of "economic activities, via markets" [1], is the only mantra that seems rational and practically possible. As history holds witness, planned economies such as that of the Soviet Union and other nations' isolationist and protectionist trade policies (even in a country like the United States that embraces free-trade), had fallen short in comparison, particularly in terms of integrating a global economic infrastructure that could alleviate the livelihood of people at large, both in developed and developing nations. It is also true that Wolf's reliance on a globally effective democratic political order and economic liberalization is highly overstated in his treatise, especially if one takes into account the recent political instability in a democracy like Zimbabwe with Mugabe's land-nationalization policies, or the case of many countries in Central Asia and sub-Saharan regions that are almost altogether devoid of any modern-day benefits of globalization, including basic everyday necessities [13].

There is no doubt that Wolf's insistence on economic globalization through free-trade and unrestricted labor movement is at the heart of his thesis as the only route to an improved and integrated world, as opposed to the upholders of localization, whose aspirations he believes, are "national, or better still, local self-sufficiency" [1]. These anti-globalization critics strongly propose that liberal global trade should be replaced by localization, for the fact that free-market globalization creates deflation in developing nations, is exploitative of its labor, threatens the environment, undermines the development strategies of developing countries and its organizations (WTO, IMF, etc.) and are anti-democratic, being protectionist themselves [1]. Moreover, critics of liberal democracy and free trade economy, such as John Gray, argue that free markets are in fact a careful creation of "artifice, design and political coercion," represented to a large extent by the interests of transnational corporations [14]. On the contrary, economic localization proponents, often referred to as the "new millennium collectivists,' oppose long-distance trade, outsourced capital-flows and labor migration, primarily on grounds that "any nation or community's security would be better enhanced if its own people could grow their own foods," and that "these self-sufficient regional, national and local economies would be less harmful to the environment than a global economy," being away from global, corporate competition [1].

Though the localization experts propound collective control and identity creation, it is at a restricted local level [1]. Wolf criticizes their appeal for economic localization as being tyrannical, shortsighted and antidemocratic. In essence, then, it is a form of localization, not only of trade, but also of labor and immigration. On the other hand, the same process of localization, if seen from a different standpoint, also espouses collective control and identity creation, but from a transnational perspective, wherein first and second generation immigrant communities in the U.S. find strategies to "forge and sustain multi-stranded social relations that link together their societies of origin and settlement" [15].

The local, socio-cultural productions of diasporic identities are dialectically related to both their ancestral and transnational identities in ways that are both ideological (assimilative) and material (primarily economic). This dichotomy makes the skilled Indian immigrant class a primary site where local and global processes congregate and also contradict each other, rendering their migration "not simply of transnationality and movement, but of political struggles to define the local as distinctive community, in historical contexts of displacement" [15]. Whether immigrants can entirely and successfully function in two cultures over a long period of time remains an open question, as does the dilemma of whether second-generation Indian immigrants can be considered transnational [5].

Post-1965, U.S. political ideology has shifted expectations to a model of cultural pluralism from its earlier insistence on forms of immigrant assimilation, although the withstanding black/white/brown racial schism of American society still remains as an informal set of folk categories. At this socio-political juncture, migrant groups, "including new immigrants, are officially encouraged to retain, and even to recreate their 
separate ethnic identities as part of their celebration of 'Americanness'...(and) within this cultural climate, Indians have been quick to create customs and institutions representing their Indian heritage" [5].

This dichotomy further emphasizes the divided cultural, political, national and transnational loyalties of NRIs and skilled H-1B workers in the U.S., who are often torn between an obligation toward the technical and business principles of their adopted America, nostalgia for their beloved Indian homeland, and membership in the globalized world of high-tech free enterprise [5]. These are the members of a localized global world that "is American inflicted but international - and impatient of the restrictions on profit posed by nationalist interests and Local cultures" [5].

The socio-cultural view of localization, as an inherent part-and-process of globalization, is also advocated by Arjun Appadurai [16], in addition to pointing out the economic and fiscal benefits of skilled immigration. He speaks of the U.S. as a delocalized transnation where various immigrant communities converge among diverse ethnic backdrops to put "loyalty to a non-territorial transnation first, while recognizing that there is a special American way to connect to these global diasporas" [16]. He also argues that the U.S. as a cultural site, "is being invited to weld these two doctrines together, to confront the needs of pluralism and of immigration, to construct a society around diasporic diversity," amidst all opposing appeals for nationalistic and patriotic loyalties [16]. In the post-national, global and diasporic space, it is only through the amalgamation of ethnoscapes ${ }^{1}$ and finanscapes ${ }^{2}$ that "the incapacity of the nation-state to tolerate diversity (as it seeks the homogeneity of its citizens, the simultaneity of its presence, the consensuality of its narrative, and the stability of its citizens) may, perhaps be overcome," to create a more global sense of locality [16].

\section{Framing The Globalization-Migration Debate}

The U.S. political economy is being altered to a large extent by the forces of neo-liberal globalization, skilled labor immigration, and reverse-migration especially during this transitional phase following the recent economic recession. Because immigration of H-1B workers to the U.S., particularly from India, has become an intrinsic element of the nation's and the globe's economic workings, the agents of globalization, both for and against the process have created rhetorical frames of pro and anti-immigration to deal with the issue. The construction of frames or framing helps in creating discursive meanings and interpreting or challenging existing rhetorical frames, being "an active processual phenomenon that implies agency and contention at the level of reality construction" [17]. According to Benford \& Snow [17], frames delineate an issue by creating meaning significations, identify the problem, establish who all are accountable, and also determine which issues should get primacy over others [18]. So, if the brunt of the continuing U.S. economic crisis on professional and skilled Indian immigrants is considered the dominant frame, then the supporting frames address: (i) the implications and consequences of a globalized and economically motivated rhetoric of skilled Indian immigrants in the wake of post-recession U.S. and (ii) the political rhetoric of the government, as it deals with the skilled labor immigration issue in favor of a more 'localized' and nationalist economic infrastructure.

Thought from a cultural perspective, the counter-frames are: (i) the frame employed by skilled immigrant workers, who propose a more inclusive pro-globalization rhetoric that will safeguard their legal status in the U.S. "as the international economy becomes increasingly globalized," and as transnationalism emerges "as a perspective necessary for understanding the new and dynamic realities of immigration" [19]; versus (ii) the more traditional forms of assimilation, with the government and immigration experts attempting to frame either "a set of strategies and policies to successfully incorporate immigrants into the national social fabric and the larger political economy" of America, or to frame policies that would completely close the doors of unchecked migration, if it posed a threat to the advancement of national economic growth [19]. In other words, the political frames employed are the pro and anti-immigration frames; the economic frames employed are pro-globalization and anti-globalization (localization) frames; while, the cultural frames employed are transnationalism and assimilationist frames.

The significance of such political and economic debates is established on the basis of two factors, (i) around which issues are they framed and (ii) who are the agents responsible for framing those debates. Although what is not evolving is the work of proper social movement organizations (at least not in the formal, organized sense), the agency lies in the active involvement of the government and the skilled Indian immigrants in the pro and anti-immigration debate. If we build on Benford and Snow's [17] framing theorization, then this global-

\footnotetext{
${ }^{1}$ Ethnoscapes can be defined as a landscape of itinerant people, such as tourists, immigrants, refugees, exiles, skilled workers, etc. who constitute an essential feature of the global world and contribute significantly to the politics, economics and cultures of their host and home countries [16].

${ }^{2}$ Finanscapes can be defined as movement of global capital, taking into account the very complex and sophisticated fiscal and investment flows that link two or more corresponding economies through a global network of currency speculation, capital and skilled and unskilled labor transfer [16]
} 
local dialectic can be considered an active framing process in the sense that the role of the immigration-debate within globalization is an ongoing one even post-recession, and it is interpretive in the sense that it gives rise to the possibility of counter-frames that not only challenge the existing restrictionist immigration policies of the U.S., but also propose alternative frames that may either advocate "free migration" [1] or more comprehensive immigration reforms that help to fortify the H1-B holders' legal and economic positions in the U.S.

The rhetoric of transnationalism proposes that the U.S. should maintain and encourage global and economically driven immigration policies. It reiterates that migration is no longer a location-specific process and that as the world economic infrastructure shifts from a more state-centered system to a globalized one, without strict trade barriers and limits to labor transmutability, "traditional immigrant issues such as citizenship, political incorporation, and cultural assimilation are being rapidly transformed" [19]. The fact that migrants are able to communicate with and between their sending and receiving societies with equal ease is made clear by our case study where the desire for permanent residency or citizenship acts as an extra impetus for the H-1Bholding Indian immigrants who want to fortify the U.S. economy by applying the specific skills that they have imported from India and who also "are able to maintain strong economic, cultural, political, and physical ties to their place of birth" [19].

Duke University professor Vivek Wadhwa has researched that immigrant students' and professionals' keen focus on technology and science has benefited the U.S. economy and driven innovation, with many immigrant-founded companies producing $\$ 52$ billion in sales and employing almost 500,000 workers in 2005 alone [20]. Wadhwa also referred to a study by William R. Kerr and William F. Lincoln (2008), which "found that in periods when H-1B visa numbers went down, so did patent applications filed by immigrants [in the U.S.]. And when H-1B visa numbers went up, patent applications followed suit" [20].

Immigration activists say that such statistics strengthen the case for legislative changes that would make it simpler for skilled immigrants to get employment and seek residency in the U.S. Further, they advise that the absence of comprehensive immigration reforms would lead to the forced reverse-migration of these skilled immigrants, with outsourcing as the only available option left to the U.S. to tap global talent [2]. A report published by the United States Commission on Immigration Reform (Commission) entitled Legal Immigration: Setting Priorities, critiques the United States' immigration policies on the basis that the policies do not give enough preference to skill based employment and entrepreneurial investment immigration [19]. Although the Commission's critique of the United States' immigration policies is predominantly economically driven, it also points toward the other factors responsible for immigrants wanting U.S. citizenship (or in some cases dual citizenship): federal aid necessities, the cost of renewing H-1B visas and/or green cards; versus the cost of acquiring U.S. citizenship, the validation of undocumented immigrants by the 1986 Immigration Control Act, and a clause in other nations' laws that allows immigrants to have U.S. citizenship and also maintain property rights in their home countries [19].

There continues to be concern among pro-globalization agents, namely Indian H-1B immigrants about how the continuing credit crisis would influence U.S. lawmakers who are opposed to immigration reforms. Often the contention is that the primary framers of an issue conveniently shut out some voices from the mainstream debate. Indian immigrants employed on H1-Bs voiced their protest at this exclusion by addressing some pertinent questions and concerns to the immigration policymakers [2]. Although there was some initial pre-election optimism in 2008 that the incumbent government would be more open toward immigration reform, it soon changed with immigration issues taking a back seat both during and following the U.S. credit meltdown. This negatively impacted several H-1B workers who were in the process of applying for Green Cards (Permanent Resident status in the U.S.)

Many employment-based immigrants believed that measures should have been taken not to jeopardize their immigration status in recent lay-off crises, especially given that several lawmakers were enraged that companies receiving bailout funds had employed foreign nationals for high-wage jobs within the U.S., while laying-off U.S. citizens [2]. Furthermore, steps taken by the Congress to ascribe stringent limits on Stimulus aid going to corporations that employed skilled immigrants put many employers in a sticky situation [2]. Attorney Marilyn Fish opined that although "there is a rationale that [U.S.] companies should prefer their own workers over foreign workers," their acceptance of the Stimulus Bill clauses undermined the very basic equal rights and opportunities promise that "employers are prohibited from discriminating against workers on the basis of national origin, and (that) employers that show bias could be vulnerable to charges of illegal discrimination" [2].

Some skilled H-1B holders believed that the only way to burst the credit and housing-crisis bubble would be to expedite immigration reforms and bring in more skilled immigrants as part of the rescue plan. "All you need to do is grant visas to two million Indians, Chinese and Koreans," said the editor of The Indian Express newspaper Shekhar Gupta [20]. "We will buy up all the subprime homes. We will work 18 hours a day to pay for them. We will immediately improve your savings...And we will start new companies to create our own jobs and jobs for more Americans," Gupta added further [20]. As impulsive and braggadocio as that sounds, Thomas Friedman also agrees that in this age of globalization the only thing that can grant U.S. 
corporations competitive advantage is skilled talent from around the world. The surest way to create more jobs for the U.S. and boost its economy is not to blame the recession or the brain-drain on skilled immigrants, but enrich its knowledge economy by stimulating all the resources that will attract more foreigners to immigrate with their valuable skill set. Moreover, as the proponents of liberal globalization would argue, the recent economic recession has made matters much worse for skilled immigrants. According to Wadhwa, when U.S. nationals who have the abilities to file patents and develop new technologies lose their jobs, they become entrepreneurs staring their own ventures, which generate employment and help the economy recover. When workers on H-1B visas get laid off, they usually have no choice but to return home and start their companies abroad. Thus they plant the seeds for future economic growth in their home countries, seeds that could easily have been planted in the U.S. [4].

In keeping with the pro-immigration frame, the U.S. should try to retain foreign graduates and skilled H-1B workers so they can create companies and curtail economic downturn, thereby challenging the localization frames that espouse generating and keeping the wealth at home [4] [21]. "Rather than inciting populist sentiment against foreigners and fostering a new nativism, policymakers could instead provide incentive programs to encourage foreign immigrant entrepreneurship, perhaps pairing fast-track residency status with launching of companies," says Wadhwa [4], vying for more relaxed immigration reforms.

Friedman writes in the New York Times op-ed column that for many NRIs and skilled immigrant workers, the recipe of U.S.'s global economic success was not a result of "protectionism, or state-owned banks or fearing free trade" [20]. They prescribed a formula that almost mirrors Wolf's appeal for open migration policies and minimal trade barriers that will operationalize globalization by building a "really flexible, really open economy... pour into it the most diverse, smart and energetic immigrants from every corner of the world and then stir and repeat, stir and repeat, stir and repeat" [20]. While Friedman does think that President Obama was trying his best to rid the Stimulus plan of the worst protectionist policies, the U.S. Senate voting on February 6, 2009 restricted banks and financial institutions that were to receive bailout funds from hiring skilled immigrants on $\mathrm{H}-1 \mathrm{~B}$ visas [20].

This brings us to the political frame of anti-immigration. The rhetoric used by the government to deal with the skilled foreign national immigration issue, is in favor of localization and a nationalist economy that proposes either an assimilationist frame, which "clearly stresses the individual migrant's incorporation into the larger political economy," while still creating jobs for U.S. nationals [19], or a more stringent frame that would greatly restrict open-migration of skilled workers if it resulted in a decline of national economic growth. Department of Homeland Security statistics for 2009 show that since 2005, Indian-owned companies accounted for almost $12 \%$ of all new H-1B employees, out of which corporations including Infosys Technologies Ltd., and Wipro Ltd., employ thousands as their U.S. staff. The main task of Indian outsourcing companies is to acquire the required skills in order to perform critical tasks in India at a fraction of the cost that it is performed in the U.S. [2].

Moreover, the critics of immigration argue that the threat of outsourcing global talent is highly overstated. Recent statistics show that there is a six to eight year backlog of petitions for Green Cards, which proves that Indian immigrants still want to settle in the U.S., amidst the continuing uncertainty of post-recession, even if they had to settle for lower wages than their U.S. citizen counterparts [7]. So deep-seated is the fear of globalization of immigrant labor that the framers of localization challenge the need for foreign skilled workers by saying that even when immigrants are offered the same (or lower) wages as their American colleagues, their mere presence increases the competition for U.S. jobs, causing a decline in pay [2].

Is job scarcity and concern about the adulteration of national identity by ethnic cultures making the U.S. re-evaluate the value of free trade and open-immigration? Ironically, this unease with immigration as a part and parcel of globalization is based on the sluggish economic development of the rest of the developing world [22]. Ron Hira, a public policy professor and opponent of immigration challenged the specialty of the H-1B specialist workers on the basis of the 2005 U.S. Department of Labor (DOL) report, which stated the average annual salary of a skilled immigrant with a master's in computer-science as $\$ 50,000$, "comparable to the $\$ 51,000$ median salary paid to entry-level U.S. workers with only a bachelor's degree" [2]. This has led to many immigration critics questioning the validity of foreign-worker certification by the DOL, with some H-1B indignities also coming to the surface. This was made clear by the indictment of 11 individuals in six states who had allegedly recruited $\mathrm{H}-1 \mathrm{~B}$ workers but had no jobs for some of them, while a few were placed with noncertified employers, "displacing qualified American workers and violating prevailing wage laws" according to a USCIS report [2]. A series of such H-1B related scandals prompted Sen. Durbin and Sen. Grassley to pass a bill in April 2009 that would grant the government greater authority to investigate employers suspected of abusing $\mathrm{H}-1 \mathrm{~B}$ rules and prevent corporations from replacing U.S. nationals with $\mathrm{H}-1 \mathrm{~B}$ immigrants. Not only did this legally prohibit the H-1B cap from increasing further, but the H-1B workers who were let go during the period of economic downturn were restricted to finding work only incorporations that were certified to hire $\mathrm{H}-1 \mathrm{~B}$ workers, within a period of 30 days (in other words, companies that had not availed the Stimulus Package or 
were a part of the TARP). Most of them had to comply with very stringent immigration rules while they were in their unemployed status in the U.S., and several had to go back to India, in no particular order [2] [7].

The controversy surrounding the return of several Indian $\mathrm{H}-1 \mathrm{~B}$ workers to India has also incited rhetoric, both anti-and pro-immigration and globalization, which further makes salient the political and economic frames used to understand this issue [7]. Wadhwa [4] advocates the relaxing of immigration restrictions on H-1B visas by the U.S. government to Indian immigrants on employment-based visas, because of their serious contributions to economic globalization. His analysis, however, seems contradictory to advocates of localization who believe that the problem of Indian graduates and H-1B workers returning to India postrecession has more to do with the uncertainty of the global economy and the aftermath of the recession, than with legal restrictions on immigration posed by Congress. As Professor Ron Hira argues, "rational people will go where the jobs are, and the jobs are in India and China" [2], the two rising contenders within the global market economy. Also expressing doubt about the statistical reliability of Wadhwa's data, B. Lindsay Lowell, Director of Policy Studies at Georgetown University's Institute for the Study of International Migration, believes that the return-migration of Indian H-1B workers and graduate students "reflects the state of the U.S. economy at the moment" [21]. To add to that, "The labor market is pretty soft... corporations are tightening their belts. At the same time, India is apparently doing pretty well. So why not return?" [21]. Based on these observations, Lowell argues that the government should frame its immigration policies on the basis of randomly selected and more reliable administrative data, all of which goes to show that the return of Indian immigrants from U.S. to India is really more a matter of economic facility than a drain of the assets of globalization [21].

\section{Conclusion And Future Discussion}

In the transitional uncertainty of the post-recession landscape, the globalization frame seems both a bane and a boon for framing the skilled-worker immigration issue. The critics of globalization argue that immigrants change the social fabric of the place to which they migrate. They import their own traditions and drain the host-society's economy, in favor of global market-alignment and an abstract transnationalism that defies notions of place-based politics, nationalism, patriotism, and cultural specificity [23]. Economists like Bob Sutcliffe and Robert Wade are of the opinion that the voluntary movement of labor is actually an exception to globalization [24] [25]. In fact, at the policy level, globalization does not support immigration, but propounds a kind of counter-globalization frame because the political policymakers pose restrictive efforts to check the migration of people to developed nations. Although they do agree that opening up of international borders and broadening the immigrants' rights in the host country are sensible policies to propose in this age, they also realize the practical impossibility of this proposition [24] [25].

With the rise of economic liberalization in developing countries, the concept of migration of locally trained professionals to the U.S. is not regarded as brain drain by the upholders of globalization. They view it as a process of accumulation of special skills that may only enhance the domestic economy, particularly if the skilled NRIs decide to return home. Although the transfer of earned funds from skilled immigrants to their home-economies are usually insignificant, the opponents of neoliberal globalization regard skilled migration of H-1B workers as a "unilateral transfer of resources, like the "drain" of the colonial period, from the underdeveloped to the developed economies." Further, localization pundits argue: "unless authoritarian, and hence repugnant, restrictions are placed on the physical emigration of skilled personnel by underdeveloped countries' governments, an element of "brain drain" is inevitable" [10].

Interestingly, the irony lays in the fact that the education and instruction curriculum in countries like India are so geared toward the foreign market, that application of those skills within the domestic economy falls short of global expectations. No doubt that this kind of globalization of learning in India and other developing countries requires a good amount of localization for the benefit of Indians getting jobs within the local market. However, till that happens, the localization experts will continue to believe that "there is no harm in viewing such emigration as an export of services, provided the economy earns sufficient foreign exchange in return to cover the expenditure socially incurred on the education and training of the emigrants, and something more." They recognize that in these neo-liberal, post-recessional circumstances, it is still not practical for progressives in developed economies, like the U.S. to support porous borders [10].

It is also true that during times of recovery from economic slump, the political resistance to immigration for employment becomes more acute. As follows, it is during such instances that the government in developed countries ascribes to the conformist anti-immigration frame that blames skilled immigrants for the paucity of jobs, irrespective of whether that is true or not [10]. It is no surprise that during such periods of economic, social and legal limbo, skilled immigrants in advanced countries like the U.S. feel particularly vulnerable about their financial, political and cultural status.

In response, the proponents of the discourse of globalization who favor a more globally aligned politics of immigration have brought to the fore the limits of the immigrant assimilation model that advocates a localized discourse of difference [26]. The transnational experience of H-1B Indian immigrants has to be 
analyzed in the context of a globalization that is not just predicated on the dynamics of economic advantages and disadvantages, but through the politics of dislocation, made all the more blatant by the aftermath of economic recession and the accompanying policy changes and socio-cultural challenges that come with it. Transnationalism, as a global and local process advocates a commercial and cultural hybrid life that makes it easy for immigrants, such as the Indian immigrants on H-1B visas, balance the politics of professional and ethnic dynamics that is present in the U.S. on one hand, with the neoliberal economic policies that globalization has made rampant, on the other [23]. Although maintaining external ties with their homeland is a given with the advancement in communication technologies and transportation, the internally perpetuated "politics of difference within the globalized political economy complicates the analysis of ethnic processes," that govern the multicultural lives of these skilled immigrant workers [27]. Moreover, the economic frame of globalization, combined with the political frame of immigration has rendered the cultural frames of transnationalism and multiculturalism, "the cultural logic of multinational capitalism" [23] [27].

The cultural frame of transnationalism sees migration as a process that transgresses the geo-physical boundaries of nations. The idea of belonging to a nation gets redefined as involvement with politics, culture and economy become gradually displaced. Transnationalism also weakens the place-bound practice of national/local economic activity, thereby making the political and economic climate ideal for the movement of skilled labor [19].

Conventional immigration theory posits an individual's economic rationalization as the driving force behind migration and attempts to justify the infiltration of skilled immigrants within advanced nations (as in the case of H-1B Indian workers within U.S.), on the basis of their success or failure at assimilation into the American way of life. However, the transnationalism frame discards the arbitrariness of this anti-immigration frame. The advocates of transnationalism argue that the patterns of migration are as much set in local-translocal, social and cultural practices, as they are rooted within a hybrid political frame. "In other words, individuals don't migrate; networks migrate," and these socio-political networks that immigrants sustain and promote have also recreated everyday cultural practices, some that transcend locality to create a more globally viable lifestyle, and some that accept assimilation as an almost inevitable byproduct of transnationalism, not seen as any different from the altered and hybrid lives that immigrants lead in their host nations [19] [27].

There is no doubt that for immigration restrictionists, migrants emerge as the one of the main reasons for exacerbating economic disaster, especially if one follows the logic of the anti-immigration political frame. Americas Policy Program's, TransBorder project analyst Tom Barry informs that anti-immigration policy framers are proposing to "retain their dominance in the immigration debate," by "reframing the immigration issue as a threat to ever-scarcer jobs in the context of the national economic crisis" [28]. But, the plight of the skilled H-1B Indian migrants who are continued victims of the economic downturn and job-market deficit cannot be ruled out, particularly if one adheres to the pro-globalization economic perspective. The immigration debate brings to the fore many political and economic issues that have surfaced in the aftermath of the economic recession, some of them being the effects of free-trade and open-migration strategies on the U.S., the government's anti-labor policies and their impact on skilled immigrants' economic and political status, as well as the perspective of the displaced and economically uncertain migrants as they find a voice to enter the debate with a political counter-frame.

The creation and perpetuation of the myth of the U.S. being a melting pot of different cultures and ethnicities, conveniently overlooks (or even masks) the trials and tribulations that are involved in the process of immigration [19]. It is by considering the core political, economic, and cultural scope of transnational immigration, that the progressive framers of immigration policies will be able to propose feasible strategies for defying the conformist attack against skilled immigrants with temporary work visas [19]. To come back to Wolf's argument about "free migration" [1], a future possibility for progressive economy planners and protransnational political framers, it may prove beneficial to remove the restrictions on the movement of skilled labor, as utopian as that sounds. Conversely, some economists argue that an increase in FDI can increase the creation of local jobs, thereby putting a check on immigration of skilled workers, and reverse the brain drain that is so rampant in the age of post-globalization. Still others argue that the reduction of restrictionist trade barriers that opens up the export market for developing nations could help their products to emigrate, while not so much their skilled labor, however inexpensive the option may be. Given all the progressive options, the better policy to adopt (as this is an issue still under debate), would be to strike a consensus between the political and economic frames of globalization and immigration, by substituting a developing nation's competitive advantage from cheap labor to commodities, and to make sure that the immigrant's legal status while on work permits (for instance Indians on H-1B visas), is protected by the host nation, particularly during and after a prolonged phase of economic instability. It would bode well for policy makers to bear in mind that the creation and continuation of this neo-liberal fiscal-order meltdown has been a globally caused condition, which should not owe its existence solely to the presence and/or further emigration of skilled foreign labor who are presumably usurping the receiving economy's job market, while also being mindful of the ethno-cultural frames for implementing fair 
immigration policies that would help maintain social justice for skilled migrants and create respect for their ethnic and cultural specificities.

\section{References}

[1] M. Wolf, Why globalization works. (New Haven, CT: Yale University Press, 2004).

[2] R. Zeidner, Does the United States need foreign workers? Cover Story of HR Magazine, June 2009, $42-47$.

[3] U.S.C.I.S., H-1B specialty occupations, DOD cooperative research and development project workers, and fashion models. Retrieved from: http://www.uscis.gov/working-united-states/temporary-workers/h-1b-specialty-occupations-and-fashion-models/h1b-specialty-occupations-dod-cooperative-research-and-development-project-workers-and-fashion-models

[4] V. Wadhwa, Don't blame H-1B workers for woes. Business Week, Feb.10. 2009. Retrieved from: http://www.businessweek.com/technology/content/feb2009/tc2009029_333899.htm?chan=top+news_top+news+index++temp technology

[5] J. Lessinger, Indian immigrants in the United States: The emergence of a transnational population. In B. Parekh, G. Singh \& S. Vertovec (Eds.), Culture and Economy in the Indian Diaspora (New York: Routledge, 2003) 165-182.

[6] C. Norman, Data shows US immigration numbers affected by economic crisis. In Global Visas, 2008. Retrieved from: http://www.globalvisas.com/news/data_shows_us_immigration_numbers_affected_by_economic_crisis457.html

[7] Immigration Policy Center, Comprehensive Immigration Reform 2014, 2014. Retrieved from: http://www.immigrationpolicy.org/comprehensive-immigration-reform-2014

[8] S. Sassen, The global city: New York, London, Tokyo. (Princeton, NJ: Princeton University Press, 1991).

[9] S. Sassen, Cities in a world economy. (Thousand Oaks, CA: Pine Forge Press, 2006).

[10] P. Patnaik, \& C. P. Chandrashekhar, Notes on international migration suggested by the Indian experience. In D. Baker, G. Epstein \& R. Pollin (Eds.), Globalization and Progressive Economic Policy (Cambridge, UK: Cambridge University Press, 1998) 357-364.

[11] K. M. Parker, Official imaginations: Globalization, difference, and state-sponsored immigration discourses. Oregon Law Review, 76, $1997,691$.

[12] G. Sabnis, Immigration - The acid test of globalization. Personal blog entry, 2006. Retrieved from: http://gauravsabnis.blogspot.com/2006/09/immigration-acid-test-of-globalization.html

[13] A. Panagariya, The miracles of globalization. Foreign Affairs, 83(5), 2004. Retrieved from: http://www.foreignaffairs.com/articles/60113/arvind-panagariya/the-miracles-of-globalization

[14] J. Gray, False dawn: The delusions of global capitalism. (New York: The New Press, 1998).

[15] S. Maira, Mixed desires: Second-generation Indian Americans and the politics of youth culture. In W.W. Anderson \& R. G. Lee (Eds.), Displacements and Diasporas: Asians in the Americas (New Brunswick, NJ: Rutgers University Press, 2005) $227-247$.

[16] A. Appadurai, Modernity at large: Cultural dimensions of globalization. (Minneapolis, MN: University of Minnesota Press, 1996).

[17] R.D. Benford, \& D. A. Snow, Framing processes and social movements: An overview and assessment. Annual Review of Sociology, 26, 2000, 611-639.

[18] R. Sen, \& F. Mamdouh, The accidental American: Immigration and citizenship in the age of globalization. (San Francisco, CA: Berrett-Koehler Publishers, 2008).

[19] A. Sanchez, Transnationalism, not assimilation. Progressive Planning, July/August, 1999.Retrieved from http://www.plannersnetwork.org/publications/1999 136/sanchez.htm

[20] T. L. Friedman, The open-door bailout. The New York Times, Feb. 10, 2009. Retrieved from:http:/www.nytimes.com/2009/02/11/opinion/11 friedman.html? r=1

[21] M. Herbst, Why the U.S. is losing foreign graduates. Business Week, $\bar{M}$ ar 9, 2009. Retrieved from:http://www.businessweek.com/technology/content/mar2009/tc20090318 162454.htm

[22] B. Milanovic, Why globalization is in trouble - Part I. YaleGlobal Online, Aug 29, 2006. Yale Center for the Study of Globalization Retrieved from: http://yaleglobal.yale.edu/display.article?id=8073

[23] I. Mukherjee, Blogs on domestic violence against immigrant South Asian women: A thematic analysis, doctoral diss., University of Illinois at Chicago, Chicago, IL, 2013.

[24] B. Sutcliffe, Freedom to move in the age of globalization. In D. Baker, G. Epstein \& R. Pollin (Eds.), Globalization and Progressive Economic Policy (Cambridge, UK: Cambridge University Press, 1998) 325-336.

[25] M. Wolf, Are global poverty and inequality getting worse? Prospect Magazine, 72(Mar), 2002. Retrieved from: http://www.prospectmagazine.co.uk/2002/03/areglobalpovertyandinequalitygettingworse/

[26] B. Bhandari, US financial crisis: Effects on India corporates. Personal blog entry, 2008. Retrieved from:http://brameshtechanalysis.blogspot.com/2008/09/us-financial-crisiseffect-on-india.html

[27] E. JR. San Juan, The ordeal of ethnic studies in the age of globalization. In W.W. Anderson \& R. G. Lee (Eds.), Displacements and Diasporas: Asians in the Americas (New Brunswick, NJ: Rutgers University Press, 2005) 270-290.

[28] D. L. Wilson, The financial crisis hits the immigration debate. Monthly Review Magazine, Nov 30, 2008. Retrieved from: http://mrzine.monthlyreview.org/wilson301108.html 